\title{
Integration of historical, archaeoseismic and paleoseismological data for the reconstruction of the early seismic history in Messina Strait (south Italy): the 1 st and 4 th centuries AD earthquakes
}

\author{
Maria Serafina Barbano ${ }^{1, \star}$, Viviana Castelli ${ }^{2}$, Daniela Pantosti ${ }^{3}$, Claudia Pirrotta ${ }^{1}$ \\ ${ }^{1}$ Università di Catania, Dipartimento di Scienze Biologiche, Geologiche e Ambientali, Catania, Italy \\ ${ }^{2}$ Istituto Nazionale di Geofisica e Vulcanologia, Torrette di Ancona, Italy \\ ${ }^{3}$ Istituto Nazionale di Geofisica e Vulcanologia, Rome, Italy
}

Article history

Received June 24, 2013; accepted February 25, 2014.

Subject classification:

Earthquakes, Historical seismology, Archaeoseismology, Tsunami deposits, Sicily, Calabria.

\begin{abstract}
Historical accounts, archaeoseismic and paleoseismological evidence allowed us to reappraise two earthquakes affecting northeastern Sicily and southern Calabria in the 1st (probably between 14 and 37) and 4th (likely between 361 and 363) centuries $A D$, to obtain a better reconstruction of their effects and to reconsider their sources. The 1st century event damaged the area from Oppido (Calabria) to Tindari (Sicily), roughly that of the February 6, 1783 Calabria earthquake. The similitude of these earthquakes is further stressed by the fact that they generated tsunamis, as recorded by historical data and by the tsunami deposits found at Capo Peloro, the oldest dated 0-125 AD, the youngest linked to the 1783 event. These earthquakes could be related to the same Calabria seismic source: the Scilla fault. Northeastern Sicily and southern Calabria were also damaged by one or more earthquakes in the 4th century $A D$ and several towns were rebuilt/restored at that time. The hit area roughly coincides with that of the Messina 1908 earthquake suggesting similar seismic sources for the events. However, because close in time, historical descriptions of the 4th century Sicilian earthquake were mixed with those of the 365 Crete earthquake that generated a basin-wide tsunami most likely reaching also the Sicilian coasts. Reevaluating location, size, damage area and tsunamigenic potential of these two earthquakes of the 1st and 4th centuries $A D$ is relevant for reassessing the seismogenic and tsunamigenic potential of the faults around the Messina Strait and the seismic hazard of the affected areas.
\end{abstract}

\section{Introduction}

Historical earthquake records can provide a significant contribute to the characterization of the seismic sources and to the understanding of the seismic hazard of an area. However, historical records need a thought- ful and careful analysis to avoid biases and over-interpretations. These problems are compounded by the limitations of the historical data, that are incomplete, often obscure, and easily susceptible of misinterpretation. Even though with these uncertainties, historical analysis represents a unique opportunity to add new tiles to that complex mosaic that is seismicity, in regions like Calabria and Sicily, in southern Italy (Figure 1a), where despite the concurrence of a long history and the presence of active faults, the main earthquakes often do not have any known "ancestor" nor a defined seismogenic source.

Active tectonics in southern Calabria and northeastern Sicily is attested by the long-term uplift rate of the coast, by landscape imprint [Guarnieri and Pirrotta 2008], coastal morphology, structural evidence [e.g. Valensise and Pantosti 1992, Monaco and Tortorici 2000, Ferranti et al. 2008], and by the frequent occurrence of strong and moderate earthquakes in recent and historical times. These earthquakes, such as the 1783 sequence and the 1908 event, had a dramatic impact on the region, however, their association with the causative faults is still debated and they are often linked with different faults / seismogenic sources (Figure 1b-e.g. Valensise and Pantosti [1992], Jacques et al. [2001], Galli and Bosi [2002], Basili et al. [2008], DISS Working Group [2010] and references therein, Aloisi et al. [2013]).

Although the Italian earthquake catalogues cover a long time span (461 BC-2002 AD) [Boschi et al. 2000, CPTI Working group 2004], descriptive data on earthquake effects are generally scarce until the 13th-14th centuries. Therefore the epicenters and magnitudes of the 


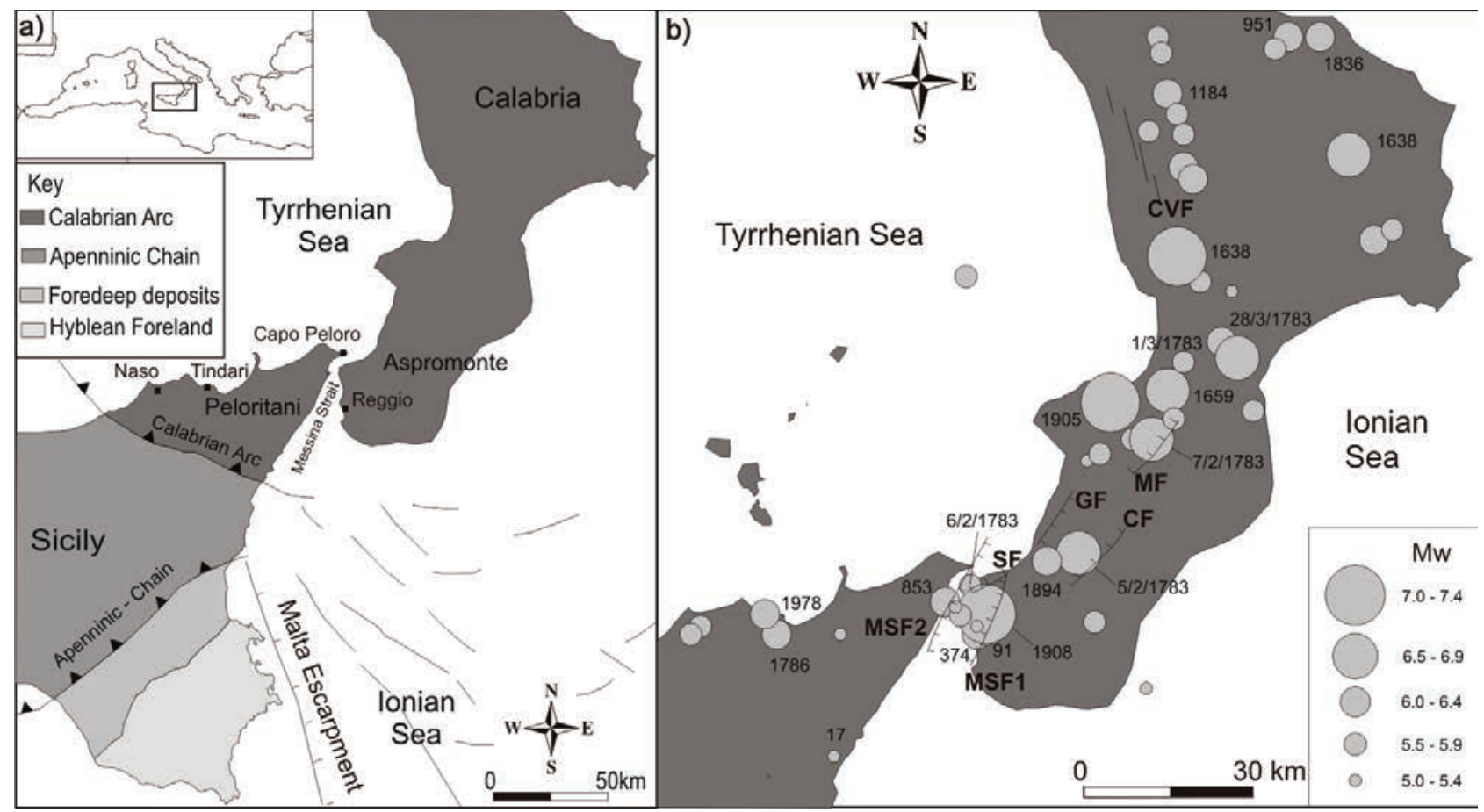

Figure 1. a) Geological sketch map of southern Calabria and north-eastern Sicily Apennine-Maghrebian Orogenic system; and (b) main historical earthquakes: epicentres (filled circles) from the CPTI4 catalogue [CPTI Working group 2004]. The faults associated with the most disastrous earthquakes are also shown: $\mathrm{CVF}=$ Crati Valley Fault; $\mathrm{MF}=$ Mesima Fault; $\mathrm{CF}=$ Cittanova Fault [Jacques et al. 2001, Galli and Bosi 2002], GF=Gioia Fault [DISS Working Group 2010], SF=Scilla Fault [Jacques et al. 2001, Ferranti et al. 2008], MSF1=west dipping Messina Strait Fault [Monaco and Tortorici 2000], MSF2=east dipping Messina Strait Fault [Pino et al. 2000, Basili et al. 2008, DISS Working Group 2010].

earlier events are roughly estimated. Since $91 \mathrm{BC}$, about $20 \mathrm{M}>6$ earthquakes (Figure $1 \mathrm{~b}$ ) occurred along the 180-km-long Calabrian Arc [CPTI Working group 2004]. Nevertheless the temporal distribution of seismicity and energy release (Figure 2) show that the earthquake catalogue is incomplete and that almost all the recorded events are clustered in less than four centuries between 1600 and 2000 AD.

Due to the catalogue's incompleteness it is possible that some events have been lost or misestimated, as shown by Galli and Scionti [2006] for northern Calabria, where they found archaeological and historical evidence of two unknown earthquakes occurred in the early 7 th century
$\mathrm{AD}$ and in 1744. Seismological studies around the Messina Strait mention some evidence of earthquakes in $91 \mathrm{BC}$, $17 \mathrm{AD}$, around mid-4th century $\mathrm{AD}$ [Guidoboni et al. 1994 2000], and in $853 \mathrm{AD}$ [Guidoboni et al. 1994, Boschi et al. 2000] but no reliable information of damage is available and the epicentral location of these earthquakes is based on a few macroseismic data points only.

Evidence coming from an excavation performed at the Torre degli Inglesi site, near Capo Peloro (Figure 1), from the necropolis of Abakainon, from archaeological studies of the Greco-Roman town of Tyndaris (today Tindari) and other sites in northeastern Sicily and southern Calabria, together with historical data, suggest that two

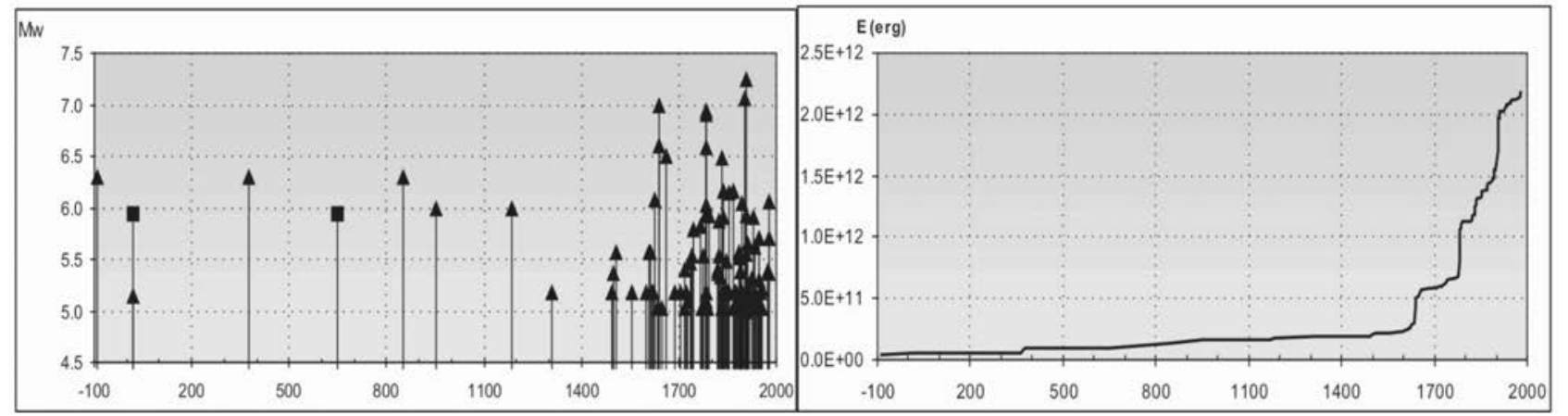

Figure 2. Temporal distribution of earthquakes in southern Calabria and north-eastern Sicily. (a) Magnitude vs. years. Squares show the 17 $\mathrm{AD}$ earthquake revaluated in this work and the unknown 7th century AD earthquake found by Galli and Scionti [2006] in northern Calabria; (b) Energy release, evaluated using the magnitude-energy relationship Log E-11.3+1.8 M [Gutenberg and Richter 1956]. Note that most of the events recorded in the catalogue occurred since 17 th century. 


\begin{tabular}{lccccccccccc}
\hline Catalogue & $\mathbf{N}$ & Year & Epicentral area & Ref & Np & Imx & Io & Lat & Lon & Maw & Me \\
\hline CPTI04 & 9 & 17 & Reggio C.-Sicily & CFTI & 2 & $8-9$ & $8-9$ & 37.800 & 15.200 & 5.14 & -- \\
CFTI4Med & - & 17 & Reggio C.-Sicily & ---- & 2 & $8-9$ & $8-9$ & 37.8 & 15.2 & --- & 5.8 \\
CPTI04 & 15 & 361 & Sicily & CFTI & 1 & 10 & 10 & 37.500 & 14.000 & 6.60 & -- \\
CFTI4Med & - & 361 & Messina Strait & --- & 2 & 10 & 10 & 38.15 & 15.6 & --- & 6.4 \\
CPTI04 & 16 & 374 & Reggio Calabria & CFTI & 1 & $9-10$ & $9-10$ & 38.100 & 15.650 & 6.30 & -- \\
\hline
\end{tabular}

Table 1. A comparison between 1st-4th century AD earthquakes in the studied area, as depicted by CPTI Working Group [2004] and CFTI4Med [Guidoboni et al. 2007-2013]. N=reference number; Year=origin time; Epicentral area: maximum effect area; Ref.: source catalogue; Np: number of macroseismic observations; Imx: maximum observed intensity; Io: Estimate epicentral intensity; Lat and Lon: geographical epicentre coordinates; Maw and Me: equivalent magnitude.

possible earthquakes in the 1st and 4th centuries occurred. In this work we reappraise all the information available on these earthquakes, with the aim of better setting their dates of occurrence, defining their effects on the human and natural environment, and improving their characterization by defining their seismogenic sources.

2. The 1 st and 4 th century earthquakes in previous studies

The most recent earthquake catalogues to cover the period under study (first half of the first millennium AD) for Calabria and Sicily are CPTI04 [CPTI Working Group 2004] and CFTI4Med [Guidoboni et al. 20072013]. The CPTI Working Group [2004] lists three earthquakes occurred in the studied area and period (Table 1): AD 17, AD 361, and AD 374.

The earthquake parameters included in this catalogue (Table 1) derive from the Italian catalogue of strong earthquakes [CFTI, Boschi et al. 2000], that on their turn derived them from Guidoboni ed. [1989]. A comparison between these two works shows that there is a difference: Boschi et al. [2000] assign the exact yearly

\section{Studies/Catalogues}

2013

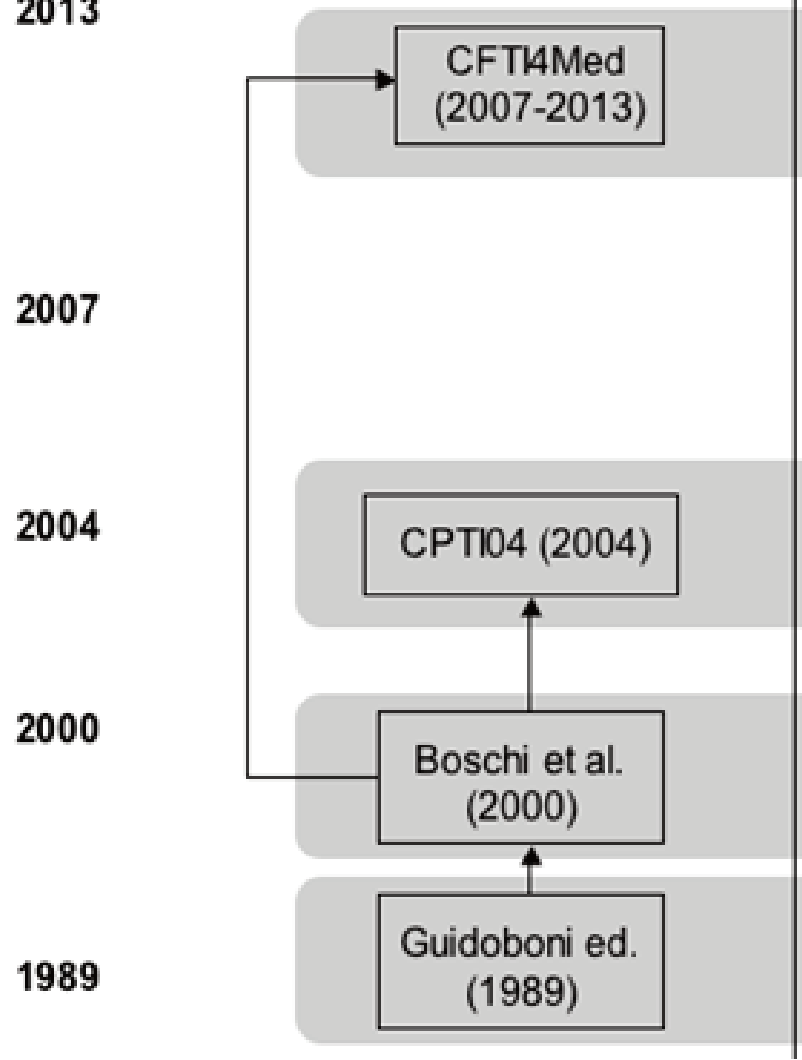

\section{Studied/listed earthquakes}

17 A.D. Reggio Calabria-Sic ily

361 A.D. Messina Strait
17 A.D. Reggio Calabria-Sic ly

361 A.D. Sicily

374 A.D.Reggio Calabria

17 A.D. Reggio Calabria-Sicily

361 A.D. Sicily

374 A.D. in Reggio Calabria

Approx. 17 A.D. in Sicily

After 361 and before July 21365 A.D. in Sicily

July 21365 A.D. in Sicily (tsunam)

Before 374 A.D. in Reggio Calabria

Figure 3. Recent studies and catalogues that deal with earthquakes in the period considered in this paper. 
dates to the three earthquakes whereas Guidoboni ed. [1989] only proposes approximate time ranges for them (Figure 3).

On the other hand, the CFTI4Med catalogue [Guidoboni et al. 2007-2013], which is based (for Italian earthquakes) on Boschi et al. [2000] "with subsequent additions and improvements", claims the occurrence of only two earthquakes in the same period. The $17 \mathrm{AD}$ event maintains the same parameters, whereas the 361 $\mathrm{AD}$ earthquake shows very different location: the middle of Sicily for Boschi et al. [2000], the Messina Strait for Guidoboni et al. [2007-2013] (Table 1 and Figure 3).

The picture of Calabro-Sicilian seismicity in the 1st4th centuries AD proposed by CFTI4Med [Guidoboni et al. 2007-2013] is more restrictive than the one outlined by Boschi et al. [2000] and by Guidoboni ed. [1989]. The latter mentions at least two local earthquakes in the 4th century, plus the effects on Sicily of the tsunami generated by the Crete earthquake of July 21, 365 (Figure 3). CFTI4Med is a "work in progress" open to later additions and improvements and subject to successive revisions (almost verbatim quote from the CFTI4Med website, as accessed on February 19, 2013). As the references quoted by CFTI4Med include the same original historical testimonies quoted by the previous studies, this changed view of the Calabro-Sicilian seismicity in the 1st-4th centuries AD should be presumably based on new interpretations of available historical data rather than on newly-acquired historical data.

\section{Historical, archaeoseismic and paleoseismological evidence: a reappraisal}

In this chapter we document new findings on the 1st and 4 th centuries earthquakes obtained by a reanalysis of

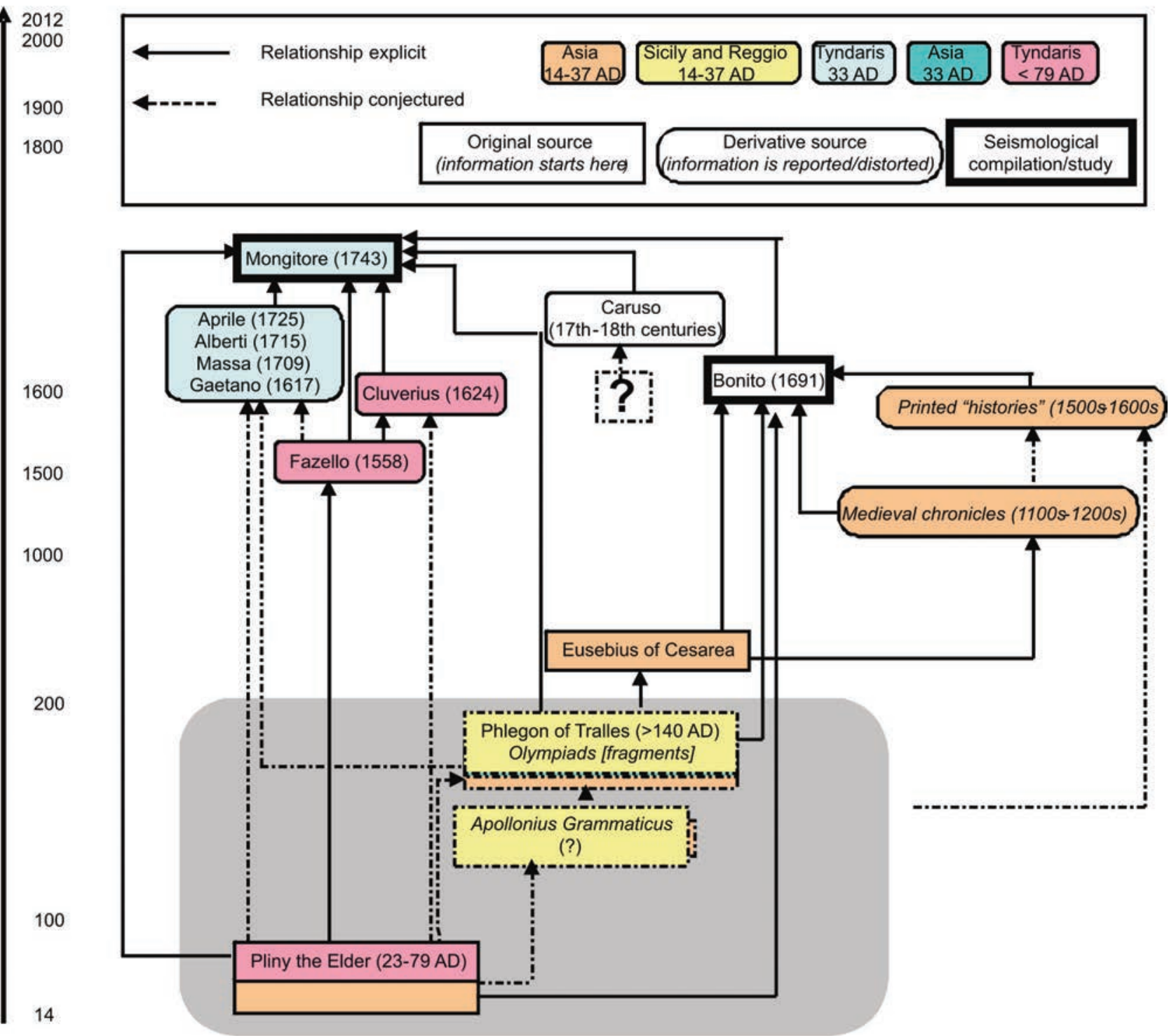

Figure 4. Flow chart of studies and sources revaluated in this study for the 1st century earthquake. Note that the Guidoboni ed. [1989] catalogue was based upon Bonito [1691] and a chronicle [Phlegon of Tralles 2nd century], whereas Mongitore [1743] used Sicilian local histories based on Pliny the Elder [1st century], as well. 
available historical sources integrated with information gathered from paleoseismic and archeoseismic investigations in order to highlight how this can contribute to a better comprehension of the studied earthquakes.

The first step of our study was the critical analysis of the knowledge collected in the seismological literature retrieving contemporary identifiable sources. To do so we analyzed both the historical sources taken into account by the recent studies that served as a reference for the parametric earthquake catalogues, and those quoted by earlier seismological compilations of which Italy has a centuries-old tradition.

Given the diversity of interpretations proposed by recent earthquake catalogues, we performed an examination of the historical data set available for each of the studied earthquakes, in order to clarify once and for all which are their respective merits, demerits and absolute degree of reliability.

The Italian tradition of descriptive earthquake studies dates back as far as the mid-15th century. Its output did mostly take the form of earthquake lists of varying size and geographical scope, from global ones such as Bonito [1691] to regional and local ones, such as Fiore [1691] and Mongitore [1743] for Calabria and Sicily, respectively. The last and best product of this tradition is certainly the great collection I terremoti d'Italia [Baratta 1901] that remains, to this day, the main data base for the parametric catalogues produced in Italy from the second half of the 20th century onwards.

The results of an extensive perusal of recent studies and older repertories allow, after having unraveled a tangle of multiple dates and spurious connections be- tween earthquakes occurred in Calabria and Sicily, in Asia Minor and/or mentioned in the Gospels, to identify two small collections of "original" historical data dealing with seismic events located in Sicily and Calabria in the required time-windows. The adjective "original" is employed here with the meaning of "nearest in time" to the described events, which is not necessarily the same as "contemporary".

\subsection{Reappraisal of an earthquake occurred in the first} half of 1st century $A D$

\subsubsection{Original information}

Figure 4 shows a flow chart of the sources quoted by seismological tradition and recent studies in connection with earthquakes occurred in Calabria and Sicily in the 1st century AD, the explicit and conjectured relationships existing between them and a summary of the dates and places mentioned by each of them.

The "original" sources are two, one that does explicitly mention the earthquake and another that does possibly mention an earthquake-related phenomenon (Table 2). The former is Phlegon of Tralles [2nd century], a Greek historian who lived at least a century after the events he recounts. The latter is Pliny the Elder [1st century], the renowned scholar and officer who was killed by the Vesuvius eruption of AD 79 .

Phlegon briefly mentions an earthquake in Sicily and the Reggio Calabria area after having described, more at length, a strong and destructive earthquake in Asia Minor (now Anatolia, Turkey). The Asian earthquake is well attested by several contemporary sources

\section{Author}

EQ date

EQ Description

Phlegon of Tralles

[2nd century]
$17 \mathrm{AD}$ (Asian EQ)

14-37 AD

(Tiberius' reign)

«Apollonius Grammaticus reports that at the time of Emperor Tiberius an earthquake almost destroyed several renowned Asian cities. Tiberius restored them at his own expenses [... Not a few towns of Sicily and the area surrounding Reggio did suffer damage from the earthquake too.»

Pliny the Elder

[1st century]
Before 79 AD

(Pliny's death date)
"The sea has carried away Pyrrha and Antissa near the Mæotian Marshes (Sea of Azov), also Elice and Bura in the gulf of Corinth, traces of which places are visible in the ocean. From the island Cea it has seized on 30,000 paces, which were suddenly torn off, with many persons on them. In Sicily also [the sea carried away] the half of the city of Tyndaris, and all the part of Italy which is wanting; in like manner it carried off Eleusina in Bøotia.» 


\section{4: Urbes haustae mari}

Pyrram et Antissam circa Maeotim pontus abstulit, Helicen et Buram sinus Corinthius, quarum in alto vestigia apparent. ex insula Cea amplius triginta milia passuum abrupta subito cum plurimis mortalium rapuit et in Sicilia dimidiam Tyndarida urbem ac quicquid ab Italia deest, similiter in Boeotia Eleusina.
94: Cities which have been absorbed by the sea

The sea has carried away Pyrrha and Antissa near the Mæotian Marshes (Sea of Azov), also Elice and Bura in the gulf of Corinth, traces of which places are visible in the ocean. From the island Cea it has seized on 30,000 paces, which were suddenly torn off, with many persons on them. In Sicily also [the sea carried away] the half of the city of Tyndaris, and all the part of Italy which is wanting; in like manner it carried off Eleusina in Bœotia

\section{5: De spiraculis}

Motus enim terrae sileantur et quicquid est, ubi saltem busta urbium exstant, simul ut terrae miracula potius dicamus quam scelera naturae. et, Hercules, non caelestia enarratu difficiliora fuerint.

\section{5: Of vents in the earth.}

But let us say no more of earthquakes and of whatever may be regarded as the sepulchers of cities; let us rather speak of the wonders of the earth than of the crimes of nature.

Table 3. Original text and English translation of Pliny's mention of Tyndaris [Bostock and Riley 1855].

and its date is certain: it took place in AD 17. The exact date of the Calabro-Sicilian earthquake is unknown; it could have occurred either in the same year of the Anatolian earthquake [as maintained by Boschi et al. 2000 and followers] or roughly about that time [as claimed by Guidoboni ed., 1989], or even, which is perhaps the safest assumption, simply during the period of Tiberius' imperial rule (AD 14-37).

Pliny the Elder mentions the partial destruction of the town of Tyndaris by the sea in Book 2 of his Natural history. This book dedicates 15 chapters (from 81st to 96 th) to earthquakes and related topics (signs of approaching earthquakes, protection against future earthquakes, circumstances attending earthquakes etc). Several of these chapters describe the interactions between sea and land which earthquakes can cause (tsunami waves, formation of islands etc). The Tyndaris episode is mentioned in Chapter 94, dedicated to the «Cities which have been absorbed by the sea» (Table 3 ).

It is uncertain whether the Tyndaris phenomenon mentioned by Pliny could have been related or not to the Calabro-Sicilian earthquake mentioned by Phlegon. Pliny does not say when the Tyndaris episode occurred. Obviously, it must have been before AD 79 (when Pliny died) but how long before remains an open question. At the end of 1st century BC (more precisely in 22-21 BC), Emperor Augustus gave Tyndaris the status of Roman colony (Colonia Augusta Tyndaritanorum). This was a high distinction in the Roman empire, indicating that Tyndaris was then an important and prosperous town. The author of the "Tyndaris" entry of the Enciclopedia Italiana [G.V.G. 1961] suggests that the partial destruction of Tyndaris could have taken place sometime after, at the beginning of 1st century AD, because the Geography of Strabo (a Greek scholar who died around 24 AD) calls Tyndaris a polisma, which is a Greek word that can be translated either as «a small town» or as «a town that used to be large but now is small» [Mogens, 1995]. If tsunami traces datable to the 1st century $\mathrm{AD}$ were to be found near the Tyndaris site and/or in other sites in northeastern Sicily, this would certainly help settling the question.

Another point which is worthwhile to concerns the actual nature of the phenomenon described by

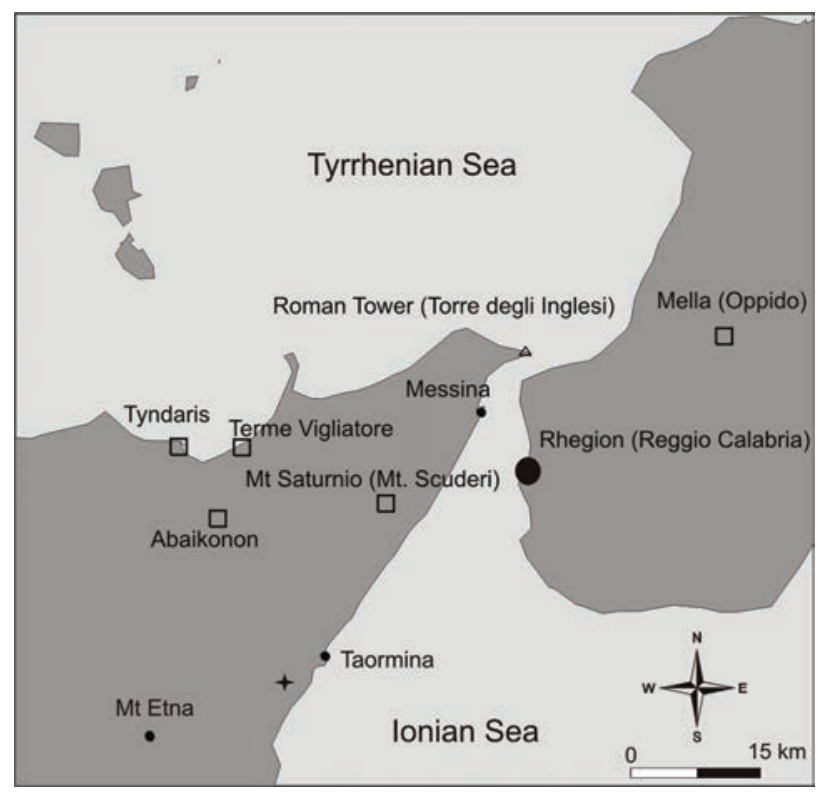

Figure 5. The $17 \mathrm{AD}$ earthquake according to Boschi et al. [2000]: Reggio and the epicenter shown by the asterisk south of Taormina; the 1st century (14-37 AD ?) earthquake/s according to this work: Reggio and the localities shown by unfilled squares. At the Torre degli Inglesi site a sandy layer interpreted as tsunami deposit dated AD 0-125 [Pantosti et al. 2008] was found (see discussion). 
Pliny. The Latin word for earthquake (terrae motus, literally "a motion of the earth") could also indicate a landslide. Tyndaris is built on a hill at $268 \mathrm{~m}$ a.s.l., so its destruction could be credited to a landslide, rather than to an earthquake-generated sea wave. However, this does not seem likely, as the specific context in which Pliny relates the episode is one of earthquake-generated marine phenomena. Moreover, recent research has shown that ancient Tyndaris included an harbour quarter placed at the foot of the hill, along a bay on the Tyrrhenian coast [Bottari et al. 2012]. It seems quite possible that tsunami affected the ancient Tyndaris harbour.

It is important to note that in later centuries the above information was subjected to much distortion on the part of derivative sources (Figure 4), which mixed up Pliny's and Phlegon's original data concerning Tyndaris and Sicily with data provided by them and other authors on the earthquake of AD 17 in Asia Minor (mentioned by Pliny elsewhere in his work) and on another Asian earthquake of $\mathrm{AD}$ 32-33. This latter earthquake was once believed - mistakenly, as pointed out by Ambraseys [2005] - to coincide with the earth-shaking felt in
Jerusalem during the crucifixion of Jesus according to the 27th chapter of the Gospel of St. Matthew [Williams et al. 2012]. This belief led several Sicilian authors of the 17th-18th centuries to blame the partial destruction of Tyndaris on the earth-shaking mentioned by St. Matthew. According to one of these authors, the earthquake described in the Gospel was responsible not only for ruining Tyndaris, but also for "cracking apart the Mount of Saturn (Mons Saturnius)" [Gaetano 1617] or "hollowing out a cavity at the foot of the Mount of Neptune" [Gaetano 1708]. Despite the multiplicity of names and circumstances he mentions, Gaetano makes it clear that the mountain in question is one and the same, located three miles inland from the coast between Messina and Taormina (Figure 5). This allows to identify it with present-day Mt. Scuderi (a $1.253 \mathrm{~m}$-high peak in the Peloritani chains). Gaetano was an ecclesiastic, with access to archive records and other historical sources that are not available anymore, so there is, in principle, at least a very slender chance that his tale does preserve, buried under heavy layers of fictionalization, a glimmer of some otherwise completely forgotten episode that

\begin{tabular}{|c|c|c|c|c|c|c|c|c|c|c|c|}
\hline Century & & & & & & & & & & & \\
\hline Site & 5 & 4 & 3 & 2 & 1 & 1 & 2 & 3 & 4 & 5 & 6 \\
\hline Mella (Oppido) & & & & & $*$ & $*$ & & & & & \\
\hline Cinquefrondi & & & & & & & & & $*$ & & \\
\hline Metauros (Gioia Tauro) & & & & & & & & & $*$ & & \\
\hline Hipponion (Vibo Valenzia) & & & & & $\mathrm{R}$ & & & & & $\mathrm{R}$ & \\
\hline Melicucco & & & & & & & & & $\mathrm{H}$ & & \\
\hline Rhegion (Reggio di Calabria) & & $*$ & & & & + & & & $* \mathrm{R}$ & & \\
\hline Bianco & & & & & & & & & $\mathrm{H}$ & & \\
\hline Casignana & & & & & & & & & $*$ & $*$ & \\
\hline Bova Marina & & & & & & & & & $\mathrm{R}$ & $\mathrm{R}$ & * \\
\hline Scolacium (Squillace) & & & & & & & & & $\mathrm{R}$ & $*$ & \\
\hline Lipari & & & & & & & & & $*$ & & \\
\hline Tyndaris & & & & & & + & & & $*$ & & \\
\hline Patti & & & & & & & & & $*$ & & \\
\hline Terme Vigliatore & & & & & & $* * \mathrm{R}$ & & & & & \\
\hline Necropolis of Abakainon & & & & & & ++ & & & & & \\
\hline Torre degli Inglesi site & & & & & & + & & & + & & \\
\hline Mt. Scuderi & & & & & & + & & & & & \\
\hline
\end{tabular}

Table 4. History of archaeological sites in southern Calabria and northeastern Sicily. Asterisks indicate the destruction phase; $\mathrm{H}$ indicates the presence of hoards; $\mathrm{R}$ are restoration/reconstruction phases; +indicates information gathered in this work. ** reconstruction phase according to Tigano et al. [2008]; ++evidence of destruction from Bottari et al. [2013]. Note the concentration of destruction/restoration and hoards in the latter half of the 4th century AD modified from Galli and Bosi [2002]. 


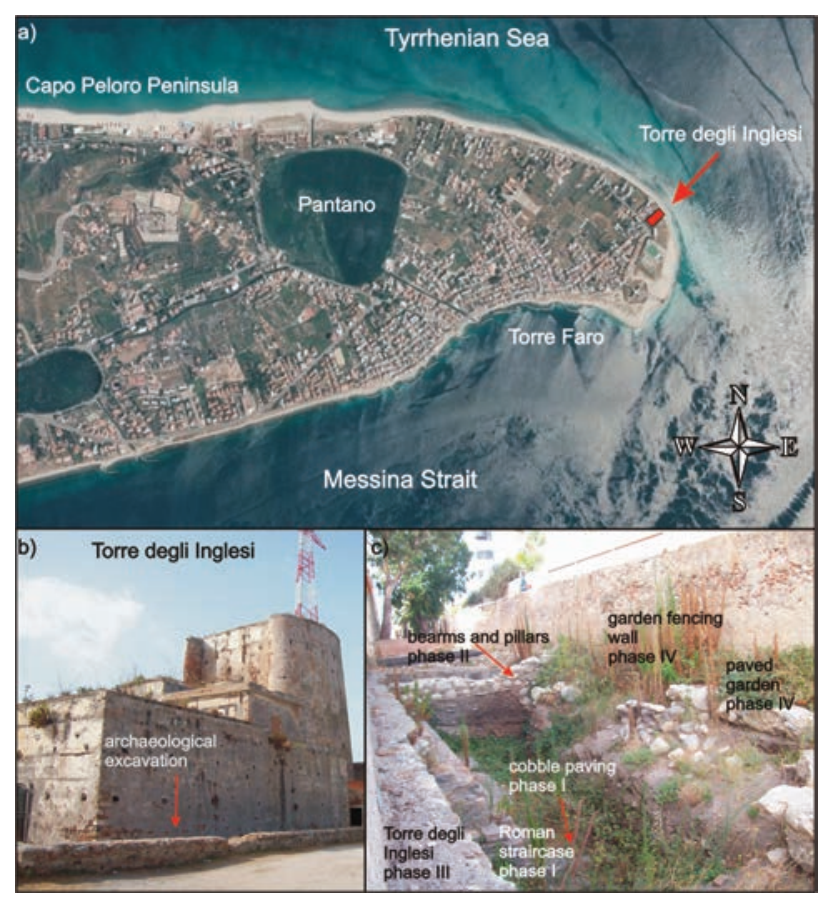

Figure 6. a) Google Earth image of Capo Peloro peninsula with the position of Torre degli Inglesi (arrow) just north of Torre Faro village that was affected by the February 6, 1783 and 1908 tsunamis. b) Torre degli Inglesi photo from NE; c) View of the archaeological excavation on the NW side of Torre degli Inglesi. The main building phases (I to IV) are evidenced and it is possible to observe the relative chronology [modified from Pantosti et al. 2008].

could have been related to the Sicilian earthquake of the 1 st century AD.

The CPTI04 catalogue [CPTI Working Group 2004], based on the CFTI [Boschi et al. 2000] whose original source is Phlegon of Tralles' account (Table 2), locates the $17 \mathrm{AD}$ event on the northern side of Mt. Etna (Figure 5).

\subsubsection{Other evidence}

Recently Bottari et al. [2013] showed that stratigraphic evidence and ruin features observed in the Necropolis of Abaikonon (Figure 5) are consistent with a seismic event and constrained the collapsing time of the fallen columns through Optically Stimulated Luminescence (OSL). Dating is coherent with a single event occurred in the 1st century AD.

In southern Calabria and northeastern Sicily sparse archaeoseismic indications concerning possible earthquakes in the 4 th and the 1 st centuries BC and in the 1st and 4th centuries AD (Table 4) have been evidenced. According to Galli and Bosi [2002], archaeoseismic analysis of the Roman farmstead built over the Hellenistic site of Mella near the old Oppido village (Figure 5), shows that it was abruptly destroyed in the 1st century AD, and its collapsed walls lie directly on the pavement of the road. This is considered as evidence for an earthquake related col- lapse. Archaeologists also document a major reconstruction in the 1st century AD of the Roman Villa of Terme Vigliatore likely damaged by a earthquake [Tigano et al. 2008].

Furthermore, from the analysis of the archaeological excavation at the Torre degli Inglesi site, a 16th century watchtower built along the coast of Torre Faro (Figure 6) on a pre-existing Roman tower, Pantosti et al. [2008] found evidence for two sandy layers that, on the basis of their sedimentological and paleontological characteristics, were interpreted as tsunami deposits. Stratigraphic and archaeological analyses and radiocarbon dating constrained the oldest tsunami sandy layer to an age range of 0-125 AD, that is compatible with an event in the 1st century AD. After this event, or soon after, the watchtower was probably modified [Crupi 2011] because the Roman steps and the water cisterns, were covered by debris containing organic material and pottery dated 1 st-3rd century (Figure 7). The youngest tsunami deposit is stratigraphically located between the 16th century watchtower basement and the 19th century pavement and enclosure wall, and was thus associated with the February 6, 1783 tsunami [Pantosti et al. 2008].

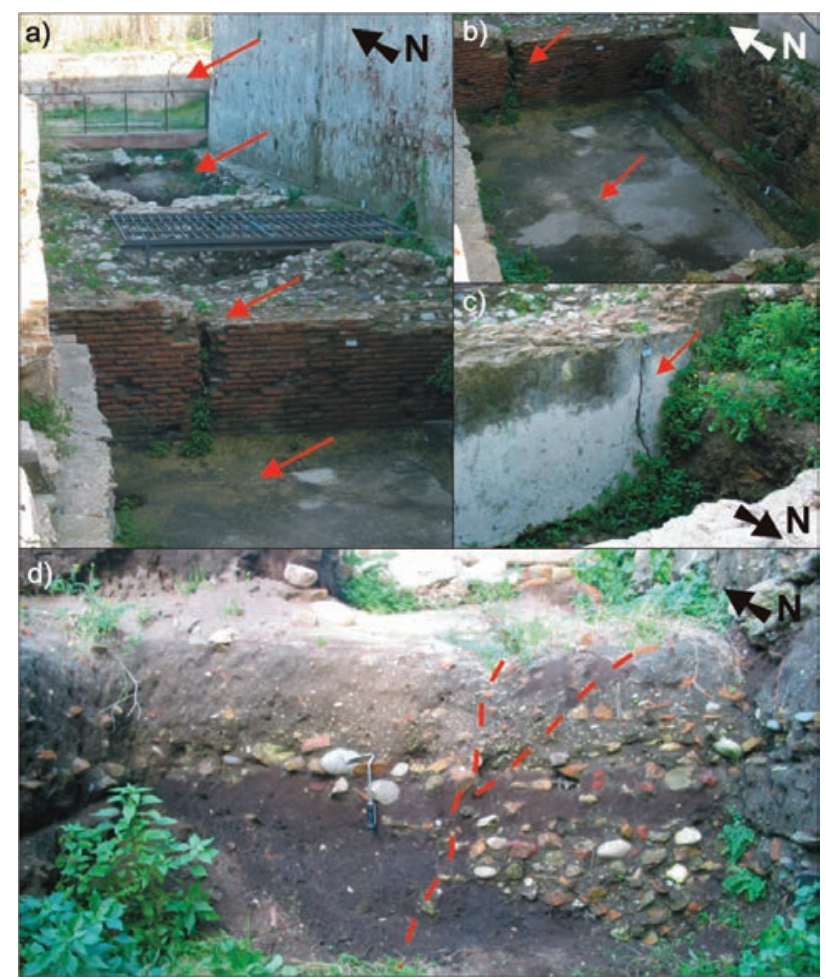

Figure 7. NE wall of the excavation at Torre degli Inglesi (see Figure 6 for location). The material infilling the cisterns dated with both archaeological and radiometric analysis shows age between 1st-3th century. Dashed red line and arrows highlight a fracture related to the 1908 earthquake, since it cuts constructions and deposits of all periods. 


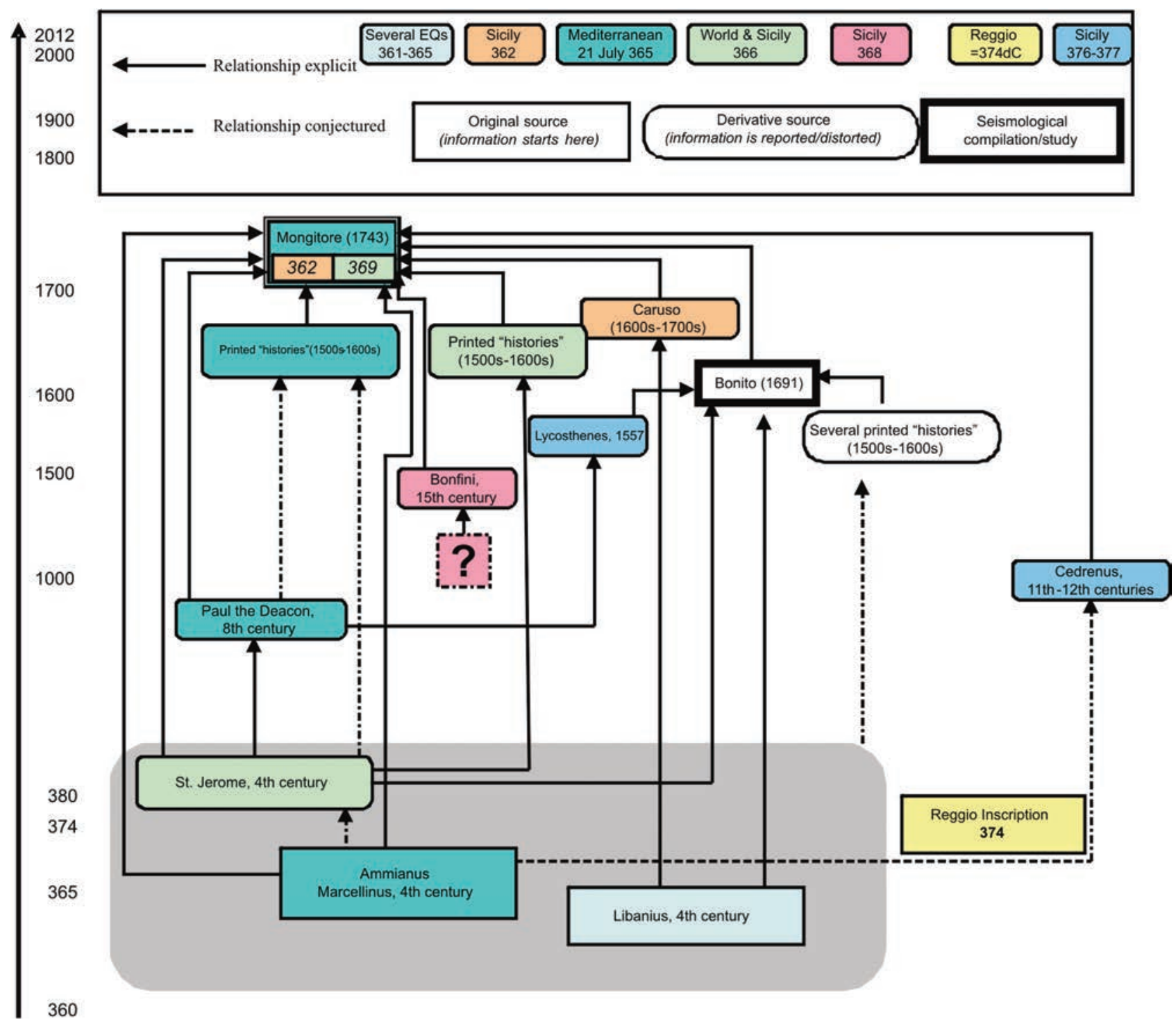

Figure 8. Flow chart of studies and sources revaluated in this study for the 4th century earthquakes.

\begin{tabular}{|c|c|c|}
\hline Author & EQ date & EQ Description \\
\hline Libanius [4th century] & $\begin{array}{c}\text { Shortly before or after June } 26,363 \\
\text { (date of Julian's death) }\end{array}$ & $\begin{array}{l}\text { "Earth truly has been fully sensible of her loss [the death of } \\
\text { emperor Julian], and has honoured the hero by an appropri- } \\
\text { ate shearing off of her tresses, shaking off, as a horse does his } \\
\text { rider, so many and such great cities. In Palestine several; of } \\
\text { the Libyans all and every one. Prostrate lie the largest towns } \\
\text { of Sicily, prostrate all of Greece save one; the fair Nicaea lies } \\
\text { in ruins [...] These are the honours paid to him by Earth, or } \\
\text { if you choose, by Neptune himself." }\end{array}$ \\
\hline
\end{tabular}

Inscription [374]

St Jerome [4th century]
Before AD 374

AD 366
«[Emperor Valentinian with Valens and Gratian] have restored the baths, which had collapsed through old age and an earthquake, to the people of Reggio [...]»

"An earthquake having occurred throughout the whole world, the shore is invaded by the sea, and falling debris in innumerable cities of Sicily and of many islands, crushed the people.»

Table 5. Original information on earthquakes occurred in the third quarter of the 4th century AD. 
3.2. Reappraisal of earthquake(s) occurred in the third quarter of the 4th century $A D$

\subsubsection{Original information}

Figure 8 shows a flow chart of the sources quoted by seismological tradition and recent studies in connection with earthquakes occurred in Calabria and Sicily roughly in the third quarter of 4 th century AD, integrated with the explicit and conjectured relationships existing between them and a summary of the dates and places mentioned by each of them.

There are three "original" sources, two of which contemporary with the described events and one slightly later: the Speeches by Libanius [4th century], an inscription of AD 374 from Reggio Calabria [Putortì 1913] and a passage in St. Jerome's Chronicle [St. Jerome 4th century], composed around AD 380 (Table 5).

Libanius was a rhetorician (professional public speaker) and a personal friend and teacher of emperor Julian the Apostate. Julian had been brought up as a Christian but later on he reverted to Paganism. During his short reign (AD 361 to 363) he attempted to outlaw Christianity - which his predecessor had made legal - and to restore the ancient Roman religion. Libanius, an enthusiastic supporter of this program, was deeply shocked by Julian's death and by the consequent collapse of his dream. These facts are important to evaluate the reliability of Libanius references to earthquakes, all of which were provided in funeral speeches he wrote for Julian's death. Libanius was not attempting to give precise information on these earthquakes for simple chronicling purposes; what he really wanted to do was to stress the magnitude of the loss caused by the death of his emperor, of which the Earth itself and the pagan god Neptune (aptly nicknamed the Earth-shaker) either foretold or mourned by causing the ground to shake and towns all over the empire to fall down. Attempts to date the earthquakes mentioned by Libanius have been made: Guidoboni ed. [1989] proposes an earthquake in Jerusalem in AD 361 and another in Nicaea (now Iznik, Turkey) in AD 362; Van Nuffelen [2006] proposes an earthquake in Palestine in AD 363 and another in Lybia (Africa) between 364 and 378. The exact date of the Sicilian earthquake remains uncertain: a possible range of occurrence could be the 361-363 time-window.

The Reggio Calabria inscription celebrates the inauguration, in $\mathrm{AD} 374$, of the town's public baths, whose renovation had become necessary after the building had

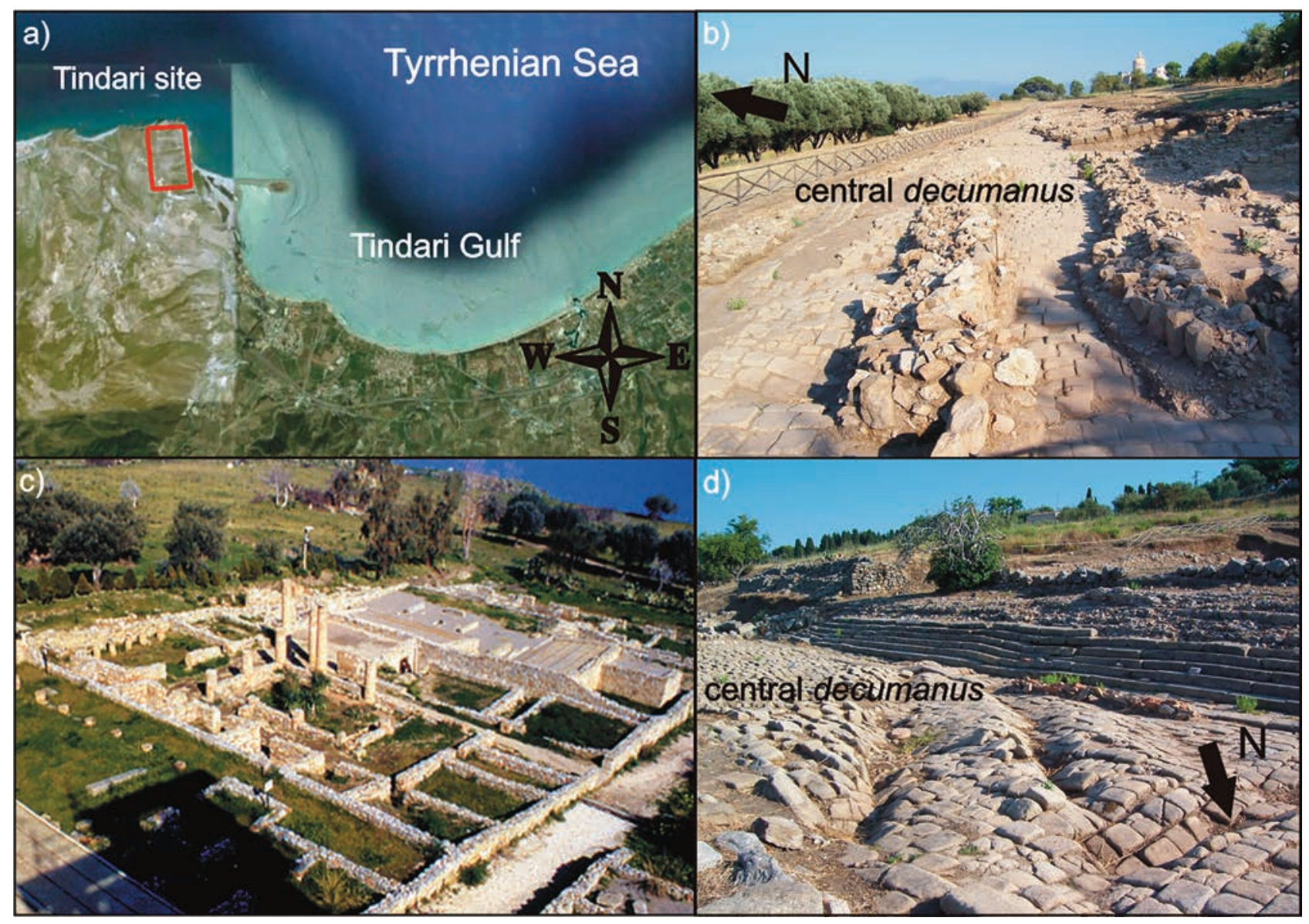

Figure 9. a) Google Earth image of the Tindari Gulf; b) the old Greco-Roman site of Tindari c) the central decumanus; d) strong undulating deformations in the road-bed of the central decumanus [Spigo 2005] associated to the 4th century earthquake. 
"collapsed because of the aging and an earthquake». This is undoubtedly a very reliable source but it does not allow to pinpoint the exact date of the earthquake it mentions. It is unlikely that this earthquake occurred in 374 [as maintained by Guidoboni ed. 1989; Boschi et al. 2000 and followers]; but a date some years earlier seems more convincing, CFTI4Med [Guidoboni et al. 2007-2013] proposes AD 361.

St. Jerome's Chronicle (a 4th century Latin translation, which update a more ancient Chronicle written in Greek by Eusebius of Caesarea) is the first historical text ever to make an attempt to accurately date all the events occurred before. As such, it had an enormous influence on later history writers that looked to it as their primary source of information on dates and events at least until the end of the Middle Ages. The Chronicle mentions a global earthquake accompanied by a tidal wave, dated in 366 , this does obviously bring to mind the catastrophic central Mediterranean earthquake of July 21, 365, which generated a tsunami which can have reached also the $\mathrm{Si}$ cilian coast. However, the description mentions human casualties caused by "falling debris in innumerable cities of Sicily", which seems hardly likely to have been caused by an earthquake located near Crete.

In this case too, as in the previous case of the 1st century event, the "original" information was subjected with time to relevant distortion, resulting in an arbitrary multiplication of earthquake dates on the part of derivative sources (Figure 8).

\subsubsection{Other evidence}

Archaeoseismic researches performed throughout southern Calabria [Galli and Bosi 2002] (Table 4) and in the cities of Messina and Reggio Calabria [Guidoboni et al. 2000] have shown the occurrence of destruction/re-

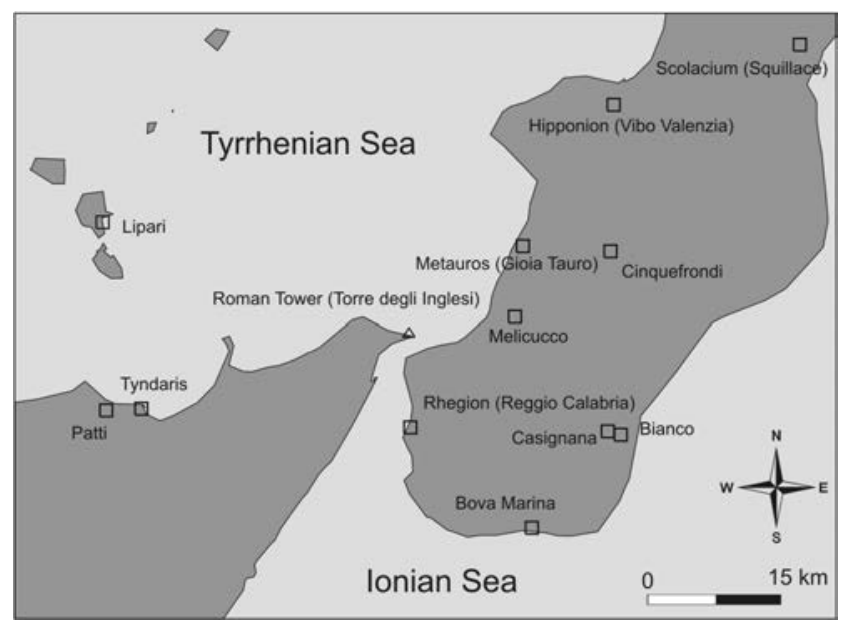

Figure 10. Index map of archaeoseismic evidence for the 4th century $\mathrm{AD}$ event in southern Calabria and northeastern Sicily. In brackets the current place names modified from Galli and Bosi [2002]. The triangle shows Torre degli Inglesi. construction/abandonment phases clustered in the 4 th century AD. Since the distribution of these archaeoseismic indications fit with the February 5, 1783 earthquake damage area, Galli and Bosi [2002] hypothesized the occurrence in the 4th century $\mathrm{AD}$ of a strong earthquake that could be the predecessor of this shock of the 1783 earthquake sequence and the "penultimate" event of the Cittanova fault (Figure 1b). On the contrary, Guidoboni et al. [2000] think that the 4 th century AD event could be a potential predecessor of the well-known 1908 earthquake located in the Messina Strait.

The 4th century event could be associated with a first modification of the Roman tower at the Torre degli Inglesi site, inferred both from the radiocarbon dating and archaeological evaluation of the organic material and pottery contained in the debris burying the Roman steps and infilling the water cisterns. This debris did accumulate before the 3rd century [Pantosti et al. 2008], and therefore probably earlier than a destructive event, after that the cisterns were probably restored [Crupi 2011].

The modern Tindari village is located near the site of the ancient Greek colony of Tyndaris (Figure 9) that dates back to the 5th-4th centuries BC. During the Greek period, in 3rd century BC, different structures were built such as a theatre, fortification walls, and towers. In the late Roman period (4th century AD) a basilica and some houses were built [Wilson 1990]. Recent archaeological excavations in the old Greco-Roman site of Tindari [Spigo 2005] have revealed earthquake-related damage attributed to the 4th century AD event [e.g. Bernabò Brea 1996], consisting of preferred orientation of the collapsed structures and strong undulating deformations in the road-bed (Figure 9d) in the central decumanus [Spigo 2005, De Domenico et al. 2006, Bottari et al. 2008].

As shown in Table 4 and Figure 10 there are also other archaeseismic data showing that Sicily and southern Calabria were hit by one or more earthquakes in the 4th century, but only for Reggio Calabria there is a direct evidence of this in the commemorative inscription.

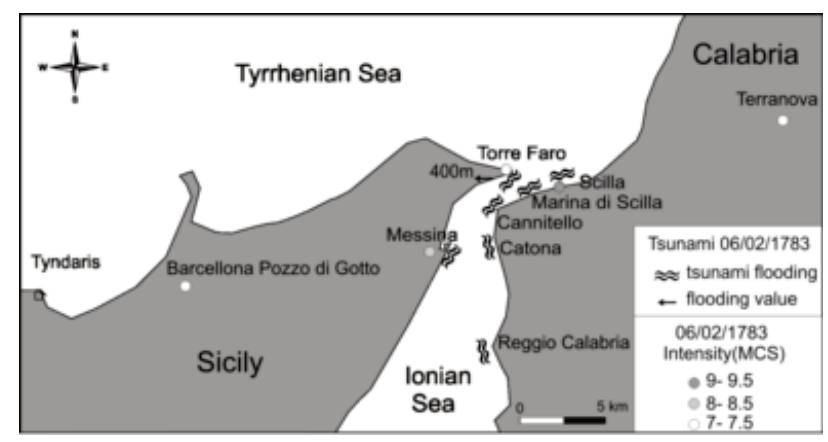

Figure 11. a) Maximum intensity data point distribution (I=7-9 MCS) for the 6 February, 1783 earthquake [data from Boschi et al. 2000]. Locations affected by tsunami are also shown [data from Gerardi et al. 2008]. 


\section{Discussion}

4.1. Was the 1st century event a twin of the 6 February 1783 earthquake?

Five earthquakes, followed by tsunamis [Graziani et al. 2006], occurred between the February 5, 1783 and March 28, 1783, causing devastation and a lot of victims in a vast region embracing the whole southern Calabria and the Messina area (Figure 1b) [Guidoboni et al. 20072013 and references therein]. Morphological and structural evidence, combined with a re-examination of observations made at the time of the earthquakes [Jacques et al. 2001 and references therein] suggest that the main shock (February 5), the first aftershock (February 6) and the February 7, third large shock were related to slip on the west-dipping, NE-striking Cittanova, Scilla and Mesima normal faults, respectively (Figure 1b) [e.g. Galli and Bosi 2002].
The hypothesis of a tsunami associated with the 1st century event is also suggested by Pliny the Elder's account "The sea swallowed up half the town of Tyndaris in Sicily (maybe the ancient Tyndaris harbour) and the coastal area of northeastern Sicily (Table 2). The Pliny's report was not considered by previous catalogues. Another event is testified at the Torre degli Inglesi site by the uppermost sandy layer, possibly deposited by the February 6, 1783 tsunami (Figure 11) before the 19th century enclosure wall was built [Pantosti et al. 2008].

Historical data report that Torre Faro (the village near which the Torre degli Inglesi building is sited) was repeatedly damaged by earthquakes located both in northeastern Sicily and in southern Calabria [Boschi et al. 2000], and inundated by the February 6, 1783 and 1908 tsunamis. The 1783 tsunami at Torre Faro flooded for about $400 \mathrm{~m}$ inland [Sarconi 1783], whereas the 1908 tsunami inundation was just $5 \mathrm{~m}$ [Baratta 1910]. Thus,

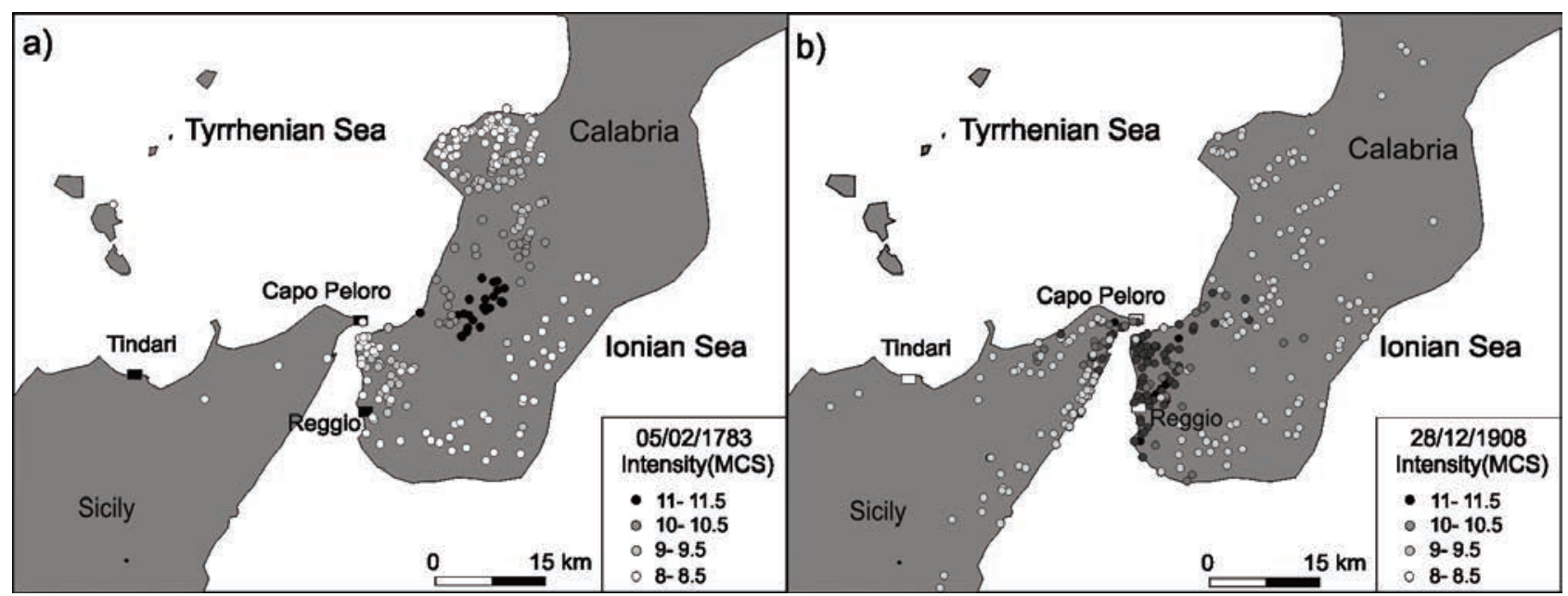

Figure 12. a) Maximum intensity data point distribution (I=8-11 MCS) for the February 5, 1783 (a) and the December 28, 1908 (b) earthquakes [data from Boschi et al. 2000].

The archaeological stratigraphy exposed at the Torre degli Inglesi site allowed to document a tsunami sandy layer, dated 0-125 AD, linked to a local earthquake occurred in the 1st century [Pantosti et al. 2008]. considering the anomalous sandy layer dated 0-125 AD at the Torre degli Inglesi site, the 1st century tsunami seems to have been capable to flood into the watchtower in the same way as during the 1783 event. This

Scilla Fault geometry and kinematics

$\begin{array}{lll}\text { Length } & \text { Dip } & \text { Slip vector } \\ 30 \mathrm{~km} & 60^{\circ} & 327^{\circ} / 11^{\circ}\end{array}$

Holocene parameters

Event pre-I

Event I

Event II

1783

Slip per event (based on footwall throw)

$2.0 \mathrm{~m} \quad 1.5 \mathrm{~m}$

Characteristic moment magnitude (on slip)

6.9

$5.9^{*}$

Characteristic moment magnitude (on fault length)

6.8

6.1

Event age BP

$5.1 \mathrm{ka}$

$3.5 \mathrm{ka}$

$1.9 \mathrm{ka}$

$0.23 \mathrm{ka}$

Table 6. Geometric and kinematic parameters for the Scilla Fault based on the displacement record of Late Holocene shorelines and fault length [modified after Ferranti et al. 2008]. *Macroseismic estimate from CPTI Working Group [2004]. 
suggests the 1st century tsunami to have an analogous source to the 1783 one (Figure 11). Moreover, the 1st century earthquake damaged Reggio, and probably the old site of Oppido (Figure 5), which was totally destroyed during the 1783 sequence [Vivenzio, 1783], and Tindari, Terme Vigliatore and the Necropolis of Abakainon which are close to the 1783 damage area, as well. These facts suggest that the earthquake occurred in the 1st century AD had a pattern of damage quite similar to that of the February 6, 1783 (Figure 11). Such an event is likely to have been located in southern Calabria and to have been energetic enough to generate a tsunami (even though we do not have enough information to estimate its magnitude and intensity). Because the 1783 tsunami was generated by an earthquake-triggered landslide [Graziani et al. 2006, Gerardi et al. 2008], this possibility could be considered also for the 1st century event.

Based on archaeoseismic indications from Calabria and NE Sicily, Galli and Bosi [2002] considered comparable the damage pattern of the 4th century event with that of the February 5, 1783 event (Figure 12a) rather than to that of the 1908 event (Figure 12b). They probably did not take into consideration the possibility of the 1 st century event as a potential ancestor of the 1783 earthquake because the earthquake catalogue presents it as a minor event located to the south near the Mt. Etna (Figure $1 \mathrm{~b}$ and 5-CPTI Working group [2004]).

Recently according to geological and geomorphological data, Ferranti et al. [2008] have recognized evidence for the occurrence of co-seismic displacements on the Scilla fault (Figure 1b). The Authors dated the most recent event at $0.23 \mathrm{ka}$ BP (likely the 1783) and the previous one at $\sim 1.9 \mathrm{ka}$ BP (Table 6). Based on fault length and slip estimated from footwall uplift and using regression relations for normal faults [Wells and Coppersmith 1994], they suggest that a $M=6.1 / 6.9$ earthquake was produced in the 1st century by the same fault responsible for the February 6, 1783 earthquake.

In summary, the available data provide evidence of an earthquake occurred in the 1st century AD (possibly between 14 and $37 \mathrm{AD}$ ) as the most likely responsible for the following circumstances: destructions in Tyndaris, in the necropolis of Abakainon, in other Sicilian towns and in the area surrounding Reggio Calabria; damage in the old Oppido site (Figure 5); tsunami deposit at the Torre degli Inglesi site; co-seismic displacements on the Scilla fault. The analogy between this set of circumstances and those related to the February 6, 1783 (Figure 11) earthquake suggests that in the 1st century one earthquake, or more, damaged the same area affected by the 1783 seismic sequence.
4.2. Was the 4th century event a 'twin' of the December 28, 1908 earthquake?

On 28 December 1908, a tsunamigenic catastrophic earthquake (Figure 12b) struck the region of the Messina Straits (Figure 1b) [Guidoboni et al. 2007-2013 and references therein]. In this paragraph, we intend to highlight the similarities between the 1908 and 4th century earthquakes.

The main historical source for the 4 th century event is Libanius that mentions several undifferentiated earthquakes occurring during the reign of Emperor Julian, among which he cites a destructive event in Sicily: «The greatest cities of Sicily lie in ruins» [Guidoboni et al. 1994]. According to several written sources and to archaeological and geological data the $365 \mathrm{AD}$ earthquake was located in Crete [e.g. Stiros 2001; 2010] but its tsunami effects are described also in mainland Greece, Adriatic sea, Sicily and North Africa [Guidoboni et al. 1994]. Furthermore, the fact that St. Jerome [4th century] reports damage and causalities in Sicily, that cannot be explained with an earthquake generated in Crete, suggests that in 4th century Sicily was affected both by a local earthquake (or more than one) and by a tsunami, likely the 21 July AD 365 tsunami. It must be stressed, however, that tsunami deposits with an age compatible to a 4th century event were detected along the coast of Southeastern Sicily: inland at Augusta [De Martini et al. 2010] and Morghella [Gerardi et al. 2012], and offshore in the Augusta bay (southeastern Sicily) [Smedile et al. 2011], and probably at Reggio Calabria [Guidoboni et al. 2000]. No tsunami evidence have been found on the Tyrrhenian northern coast of Sicily. The above mentioned authors attributed the tsunami deposits to the far Crete source but they could also have been deposited by a tsunami generated by a local event.

Stratigraphic and archaeological relations suggest that the Roman watchtower at the Torre degli Inglesi site was probably damaged after the 3rd century AD and successively restored between the 4th century and the 16th century [Pantosti et al. 2008]. During this period the CPTI04 catalogue [CPTI Working Group 2004] lists only three significant earthquakes dated at the 4 th century, $\mathrm{AD}$ 853 and AD 1509 (Figure 1b). As the age of the materials filling the cisterns can be fixed to sometime between the 2nd and 3rd centuries [Crupi 2011], the watchtower was probably restored after a damaging event, that likely could have been the 4 th century earthquake very close in time with the material found inside the cistern.

The Torre degli Inglesi site was also affected by the 1908 earthquake that caused the north-eastern striking fracture cutting through constructions of all periods (Figure 7), as reported by Baratta [1910]: «the December 28, 1908 earthquake caused E-W and N-S oriented cracks 
in the colossal $3 \mathrm{~m}$ thick walls of the Torre degli Inglesi, in which a large E-W- oriented fracture did also cause disjunction and lowering in the opened northern wall».

Hence at the Torre degli Inglesi site only evidence of damage is recognizable, both for the 4th century event and for the 1908 earthquake (Figure 7), furthermore for both these events no tsunami deposits have been found. These analogies, together with the archeoseismic evidence reported for several sites (Figure 10), allow us to hypothesize that the event occurred in the 4th century (likely in AD 361-363) could be the "ancestor" of the 1908 earthquake. Similarly to this latter one, also the 4th century event could be located around the Messina Strait and may have produced a tsunami with wave heights quickly decreasing north of Messina, not energetic enough to depose marine sand at the Torre degli Inglesi site.

Since the area of effects for the 1783 and 1908 earthquake (Figure 12) are quite similar, the 4 th century earthquake could be also associated with the same structure of the 1783, previously referred to the Cittanova fault (Figure 1).

\section{Conclusions}

The analysis of available historical, archeoseismic and paleoseismic data allowed us to improve the knowledge of two earthquakes occurred in the 1st and 4th centuries $\mathrm{AD}$ in northeastern Sicily and southern Calabria.

Different historical and archaeoseismic data suggest a situation of widespread earthquake damage in the area extending from Oppido in Calabria to Tindari in Sicily, during the 1st century AD. All this evidence could be related to a single earthquake or a seismic sequence, occurred between the years 14 and $37 \mathrm{AD}$, and that did also generate a tsunami, as recorded at the Torre degli Inglesi site and as hinted by contemporary accounts. This event could have been the predecessor of the February 6, 1783 earthquake, and generated by the same seismic source located in southern Calabria: the Scilla fault. If this hypothesis is correct, the M5 of the AD 17 event indicated in the CPTI04 catalogue [CPTI Working Group 2004] is underestimated and its location on the northern slope of Mt. Etna should be revised.

Historical data and archaeoseismic evidence suggests the occurrence of another earthquake almost in the same area hit by the 1908 earthquake in the 4 th century (most likely between the years 361 and $363 \mathrm{AD}$ ). This event probably damaged Tindari and the Torre degli Inglesi site as well. Another similitude between the 1908 event and the 4th century event is that no tsunami deposits compatible to their ages were found to the North of the Messina Strait and particularly at the Torre degli Inglesi site.
These results could have a strong impact on seismic hazard assessment of southern Calabria and northeastern Sicily. In fact, on the one side, they provide insights to establish average recurrence times ( $\sim 1300-1660 \mathrm{yrs})$ for the major seismic sources of the area and, on the other, suggest that the area is characterized by "seismic periods" that concentrate most of the relevant seismicity. Likely, a seismic period occurred between the 1st and 4th centuries $\mathrm{AD}$ as that, better known, which occurred between 1638 and 1908 (during which the entire seismogenic structure of Calabria, from the Crati Valley to the Messina Strait, $180 \mathrm{~km}$-long, ruptured).

The mutual contributions of archaeology, geology, and history demonstrate the strength of such interdisciplinary studies to contribute to knowledge of past earthquakes and to provide estimates of their probable future occurrence and location.

Survey and documentation of archaeological sites along or near active faults and paleoseismic analysis can significantly improve the knowledge of past earthquakes. New analysis, to be performed in the numerous archaeological sites in southern Calabria and northeastern Sicily, will allow a better definition of the uncertain events reported in the catalogue and to new information, for a more complete evaluation of the recurrence time of the characteristic earthquakes of this area.

Acknowledgements. The research was partially supported by the Italian Project PRIN 2010-2012, resp. C. Monaco. We wish to thank the two anonymous referees and the associate editor G. De Astis for their constructive comments and suggestions which significantly helped improve the quality of the manuscript.

\section{References}

Alberti, N. (1715). Compendio dei commentari sacrostorici della Vita, Dottrina e Miracoli di Gesù Cristo, Messina, $330 \mathrm{pp}$.

Aloisi, M., V. Bruno, F. Cannavò, L. Ferranti, M. Mattia, C. Monaco and M. Palano (2013). Are the source models of the M7.1 1908 Messina Straits earthquake reliable? Insights from a novel inversion and a sensitivity analysis of levelling data, Geophys. J. Int., 192 (3), 1025-1041. doi: 10.1093 / gji/ggs062

Ambraseys, N. N. (2005). Historical earthquakes in Jerusalem. A methodological discussion. J. Seism. 9, 329-340.

Ammianus Marcellinus (4th century). The Roman History, http:/ / penelope.uchicago.edu/ Thayer/E/

Roman/Texts/Ammian/home.html.

Aprile, F. (1725). Della cronologia universale della Sicilia libri tre, Palermo, 808 pp.

Baratta, M. (1901). I terremoti d'Italia; saggio di storia geografia e bibliografia sismica italiana, Torino, $950 \mathrm{pp}$. 
Baratta, M. (1910). La catastrofe sismica calabro messinese (28 dicembre 1908), 2 vols. Roma (facsimile print, Sala Bolognese 1985).

Basili, R., G. Valensise, P. Vannoli, P. Burrato, U. Fracassi, S. Mariano M.M. Tiberti and E. Boschi (2008). The Database of Individual Seismogenic Sources (DISS), version 3: summarizing 20 years of research on Italy's earthquake geology, Tectonophysics, 453, 20-43, doi:10.1016/j.tecto.2007.04.014.

Bonfini (15th century). Historia Pannonica, Cologne 1690, 702 pp.

Bonito, M. (1691). Terra tremante, ovvero continuatione de' terremoti dalla creatione del mondo sino al tempo presente, Napoli ( facsimile print, Sala Bolognese1979), 822 pp.

Boschi, E., E. Guidoboni, G. Ferrari, P. Gasperini, D. Mariotti, and G. Valensise (eds.) (2000). Catalogue of Strong Italian Earthquakes from 461 B.C. to 1997 , Ann. Geof., 43, 609-868.

Bostock, J. and H.T. Riley (1855), Pliny the Elder, The Natural History, London, http://www.perseus. tufts.edu/hopper/text?doc=Perseus:text:1999.02.01 37: book=2: chapter $=94$ \&highlight $=$ tyndaris \#note 1 .

Bottari, C., A. Bottari, P. Carveni, C. Saccà, U. Spigo and A. Teramo (2008). Evidence of seismic deformation of the paved floor of the decumanus at Tindari (NE Sicily), Geophys. J. Int., 174, 213-222.

Bottari, C., S. Urbini, M. Bianca, M. D'Amico, M. Marchetti, and F. Pizzolo (2012). Buried archeological remains connected to the Greek-Roman harbor at Tindari (north-east Sicily): results from geomorphological and geophysical investigations, Ann. Geophys., 55 (2), 223-234.

Bottari, C, M.S. Barbano, C. Pirrotta, R. Azzaro, G. Ristuccia and A. Gueli (2013). Archaeological evidence for a possible first century $\mathrm{AD}$ earthquake in the necropolis of Abakainon (NE Sicily), Quat. Int., 316, 190-199. http://dx.doi.org/10.1016/j.quaint.2013. 10.004

Bernabò Brea, L. (1996). Note sul terremoto del 365 d.C. a Lipari e nella Sicilia nord-orientale. In: G. Giarrizzo ed., La Sicilia dei terremoti, lunga durata e dinamiche sociali, Catania, 87-97.

Caruso (17th-18th centuries). Storia di Sicilia, 4 vols., edited by G. Di Marzo, Palermo 1875-1877.

Cedrenus, G. (11th-12th centuries). Compendium historiarum. In: B.G. Niebuhr ed., Corpus Scriptorum Historiae Byzantinae, Bonn 1838, 802 pp.

Cluverius [Johann Clüver] (1637). Historiarum totius mundi epitome, Lyon, $816 \mathrm{pp}$.

CPTI Working Group (2004). Catalogo Parametrico dei Terremoti Italiani, http: / / emidius.mi.ingv.it/CPTI/. Crupi, U. (2011). Primi elementi sul complesso idraulico connesso con la Torre Romana di Capo Peloro. In: Messina. Scavi a Ganzirri e a Capo Peloro (2003-2006) a cura di G. Tigano. Palermo, Regione siciliana, Assessorato dei beni culturali, ambientali e della pubblica istruzione, Rubbettino editore, Soveria Manelli (CZ), 61-70. ISBN 978-88-498-3264-8.

De Domenico, D., F. Giannino, G. Leucci, and C. Bottari (2006). Integrated geophysical surveys at the archaeological site of Tindari (Sicily, Italy), J. Archaeol. Sc., 33, 961-970.

De Martini, P.M., M.S Barbano, A. Smedile, F. Gerardi, D. Pantosti, P. Del Carlo and C. Pirrotta (2010). A unique 4000 yrs long geological record of multiple tsunami inundations in the Augusta Bay (eastern Sicily, Italy), Mar. Geol., 276, 42-57.

DISS Working Group (2010). Database of Individual Seismogenic Sources (DISS), Version 3.1.1: A compilation of potential sources for earthquakes larger than M 5.5 in Italy and surrounding areas, http: / / diss.rm.ingv.it/diss/.

Eusebius of Caesarea (3th-4th centuries). Chronicorum Libri duo, A. Schoene ed., 2 vols., Berlin, 1866-1875.

Fazello, T. (1558). De rebus Siculis decades duae, Palermo, 616 pp.

Ferranti, L., C. Monaco, D. Morelli, F. Antonioli and L. Maschio (2008). Holocene activity of the Scilla Fault, Southern Calabria: insights from coastal morphological and structural investigations, Tectonophysics, 453, 74-93, doi:10.1016/j.tecto.2007.05.006

Fiore, G. (1691). Della Calabria illustrata, 3 vols., Napoli (facsimile print, Sala Bolognese, 1980).

Gaetano, O. (1617). Idea operis de vitis Siculorum sanctorum famave sanctitatis illustrium, Palermo, $150 \mathrm{pp}$.

Gaetano, O. (1708). Isagoge ad historiam sacram Siculam, Palermo, 403 pp.

Galli, P. and V. Bosi (2002). Paleoseismology along the Cittanova fault: implications for seismotectonics and earthquake recurrence in Calabria (southern Italy), J. Geophys. Res., 107, B2044, doi: 10.1029/2001JB000234.

Galli, P. and V. Scionti (2006). Two unknown M>6 historical earthquakes revealed by paleoseismological and archival researches in eastern Calabria (Southern Italy), seismotectonic implication, Terra Nova, 18, 44-49.

Gerardi, F., M.S. Barbano, P.M. De Martini and D. Pantosti (2008). Discrimination of the nature of tsunami sources (earthquake vs. landslide) in eastern Sicily and southern Calabria as inferred from historical data, Bull. Seism. Soc. Am., 98, 2795-2805.

Gerardi, F., A. Smedile, C. Pirrotta, M.S. Barbano, P.M. De Martini, S. Pinzi, A.M. Gueli, G.M. Ristuccia, G. Stella and S.O. Troja (2012). Geological record of 
tsunami inundations in Pantano Morghella (southeastern Sicily) both from near and far-field sources, Nat. Haz. Earth Syst. Sci., 12, 1185-1200, doi:10.5194/nhess-12-1185-2012.

Graziani, L., Maramai, A. and S. Tinti, (2006). A revision of the 1783-1784 Calabrian (southern Italy) tsunamis, Nat. Haz. Earth Syst. Sci., 6, 1053-1060.

Guarnieri, P. and C. Pirrotta (2008). The response of drainage basins to the Late Quaternary Tectonics in the Sicilian side of the Messina Strait (NE-Sicily), Geomorphology, 95, 260-273.

Guidoboni, E. ed. (1989). I terremoti prima del Mille in Italia e nell'area mediterranea, ING-SGA, Bologna., $765 \mathrm{pp}$.

Guidoboni, E., A. Comastri and G. Traina (1994). Catalogue of ancient earthquakes in the Mediterranean area up to 10th century, vol. 1, ING-SGA, Bologna 1994, 504 pp.

Guidoboni, E., A. Muggia and G. Valensise (2000). Aims and methods in territorial archaeology: possible clues to a strong fourth-century $\mathrm{AD}$ earthquake in the Straits of Messina (southern Italy), In: W.G. McGuire, D. R. Griffiths, P.L. Hancock and I.S. Stewart (eds.), The Archaeology of Geological Catastrophes, Geological Society, London, SP, 171, 45-70.

Guidoboni, E., G. Ferrari, D. Mariotti, A. Comastri, G. Tarabusi and G. Valensise (2007-2013). CFTI4 Med. Catalogue of Strong Earthquakes in Italy, 461 BC1997 and Mediterranean Area 760 BC-1500. An Advanced Laboratory of Historical Seismology, http: / / storing.ingv.it/cfti4med/ [accessed February 19, 2013].

Gutenberg, B. and C.F. Richter (1956). Magnitude and energy of earthquakes, Ann. Geof., 9, 1-15.

Jacques, E., C. Monaco, P. Tapponier, L. Tortorici and T. Winter (2001). Faulting and earthquake triggering during the 1783 Calabria seismic sequence, Geophys. J. Int., 147, 499-516.

Libanius (4th century). Monody: Funeral Oration for Julian, In: R. Pearse (ed.). Early Church Fathers-Additional Texts, http: / / www.tertullian.org/fathers/libanius_monody.htm

Lycosthenes [Conrad Wolffhart] (1557). Prodigiorum ac ostentorum chronicon, Basel, $670 \mathrm{pp}$.

Massa, G.A. (1709). La Sicilia in prospettiva, Palermo, $862 \mathrm{pp}$.

Mogens, H.H. (1995). Studies in the Ancient Greek Polis, 1, Franz Steiner Verlag, 219 pp.

Monaco, C. and L. Tortorici (2000). Active faulting in the Calabrian arc and eastern Sicily, J. Geodyn., 29, 407-424.

Mongitore, A. (1743). Istoria cronologica de' terremoti di Sicilia, In: Della Sicilia ricercata nelle cose più memorabili, t. 2, Palermo, 345-445.

Pantosti, D., M.S. Barbano, A. Smedile, P.M. De Martini and G. Tigano (2008). Geological Evidence of Paleotsunamis at Torre degli Inglesi (northeast Sicily). Geophys. Res. Lett., 35, L05311, doi:10.1029/2007GL032935.

Paul the Deacon (8th century). Historia Romana In: H. Droysen ed., Monumenta Germania Historica, Script. Rer. Germ., 49, Berlin 1879, http: / /www.dmgh.de/de/fs1 / object/display/bsb000 00771_meta:titlePage.html.

Phlegon Trallensis (2nd century). Die Fragmente der Griechischen Historiker 257, ed. F. Jacoby, pt.2 (Zeitgeschichte), vol.B1, Leiden 1962.

Pino, N. A., D. Giardini and E. Boschi (2000). The December 28, 1908, Messina Straits, southern Italy, earthquake: waveform modelling of regional seismograms, J. Geophys. Res., 105, B11, 25473-25492.

Pliny the Elder (1st century). Natural History, book 2, chap. 94, http://penelope.uchicago.edu/ Thayer/L/Roman/Texts/Pliny_the_Elder/2*.htm 1.

Putortì, N. (1913). Di un titolo termale scoperto in Reggio di Calabria, Rendiconti della Reale Accademia dei Lincei. Classe di scienze morali, storiche e filologiche, s.V, vol. 21,791.

Sarconi, M. (1784). Istoria de' fenomeni del tremoto avvenuto nelle Calabrie, e nel Valdemone nell'anno 1783, Napoli, 527 pp.

Smedile A., P.M. De Martini, D. Pantosti, L. Bellucci, P. Del Carlo, L. Gasperini, C. Pirrotta, A. Polonia and Boschi E. (2011). Possible tsunami signatures from an integrated study in the Augusta Bay offshore (Eastern Sicily-Italy), Mar. Geol., 281, 1-13, 2011.

Spigo, U. (2005). Tindari. L'area archeologica e l'antiquarium. Milazzo, $96 \mathrm{pp}$.

Stiros, S.C. (2001). The AD 365 Crete earthquake and possible seismic clustering during the fourth to sixth centuries AD in the Eastern Mediterranean: a review of historical and archaeological data, J. Struct. Geol. 23, 545-562.

Stiros, S.C. (2010). The 8.5+magnitude, AD365 earthquake in Crete: Coastal uplift, topography changes, archaeological and historical signature, Quat. Intern., 216, 54-63.

St. Jerome (4th century). Chronicle, In: R. Pearse (ed.). Early Church Fathers-Additional Texts, http: / / www.tertullian.org/fathers/jerome_chronicle_03_part2.htm

Tigano, G., L. Borrello and A.L. Lionetti (2008). Terme Vigliatore-S. Biagio. Regione siciliana, Assessorato dei beni culturali, ambientali e della pubblica istruzione, Villa romana, Palermo, $44 \mathrm{pp}$. 
Valensise, G. and D. Pantosti (1992). A 125 Kyr-long geological record of seismic source repeatability: in the Messina Straits (southern Italy) and the 1908 earthquake, Terra Nova, 44, 472-483.

Van Nuffelen, P. (2006). Earthquakes in AD 363-368 and the date of Libanius, 'Oratio' 18. Classical Quarterly 56, 657-661.

Vivenzio, G. (1783) Istoria e teoria de' tremuoti in generale ed in particolare di quelli della Calabria, e di Messina del 1783, Napoli, 56 pp.

Wells, D.L. and K.J. Coppersmith (1994). New empirical relationships among magnitude, rupture, length, rupture width, rupture area and surface displacement. Bull. Seism. Soc. Am., 84, 974-1002.

Williams, J.B., M.J. Schwab and A. Brauer (2012). An early first-century earthquake in the Dead Sea, Inter. Geology Review, 54, 1219-1228.

Wilson, R.J.A. (1990). Sicily Under the Roman Empire. The Archaeology of a Roman Province 36BC535AD, London, $464 \mathrm{pp}$.

${ }^{\star}$ Corresponding author: Maria Serafina Barbano, logiche e Ambientali, Catania, Italy; email: barbano@unict.it. 